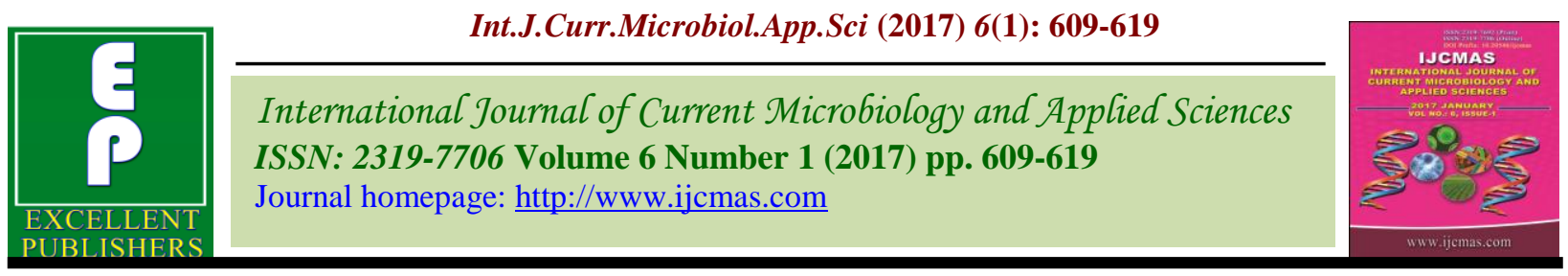

Original Research Article

http://dx.doi.org/10.20546/ijcmas.2017.601.074

\title{
Is a Retrovirus (XMRV) Risk Factor for Prostate Cancer in Indian Population
}

\author{
Kapil Bandil ${ }^{1,2}$, Anoop Kumar ${ }^{1}$, Atika Dogra ${ }^{3}$, Sudhir K. Rawal ${ }^{4}$, D.C. Doval ${ }^{5}$, \\ Anil K. Varshney ${ }^{6}$ and Mausumi Bharadwaj ${ }^{1,2} *$ \\ ${ }^{1}$ Division of Molecular Genetics \& Biochemistry; Institute of Cytology \& Preventive Oncology \\ (ICMR), I-7, Sector-39, Noida, India \\ ${ }^{2}$ Utter Pradesh Technical University, Lucknow, U.P. India \\ ${ }^{3}$ Research Department , ${ }^{4}$ Surgical Gynae Uro-Oncology, ${ }^{5}$ Medical Oncology, Rajiv Gandhi \\ Cancer Institute \& Research Centre, Rohini, New Delhi, India \\ ${ }^{6}$ R.G. Stone Urology \& Laparoscopy Hospital, New Delhi, India \\ *Corresponding author
}

\begin{abstract}
A B S T R A C T
Presently, the known gamma-retroviruses, Xenotropic Murine Leukemia virus (MLV) -

\begin{tabular}{|l|}
\hline Key w or d s \\
Prostate cancer, \\
BPH, XMRV \\
infection, \\
Xenotropic Murine \\
Leukemia virus \\
(MLV)
\end{tabular}
related Virus (XMRV) is imminent as a cancer causing infectious virus in prostate cancer. This study has been designed on retrovirus (XMRV) infection in Indian PCa patient and its co-relation with clinical pathological and demographic parameters of prostate cancer cases and Benign Prostate hyperplasia (BPH) as controls. A total of 235 prostate samples including 105 confirmed prostate cancer cases and 130 benign prostate hyperplasia (BPH) as controls were analyzed for XMRV infection. We have used Nested -PCR method for XMRV detection followed by sequencing. Statistical analysis was done by Graphpad Instat version 3.3 for co-relation between XMRV status and clinical pathological parameters of prostate cancer cases and BPH controls. Out of 235 prostate samples, XMRV was detected 5.4\% (7/130) in BPH tissue samples and 7.6\% (8/105) in PCa tissue samples. Patients with higher PSA level were found to prone for XMRV infection in both $\mathrm{PCa}$ as well as BPH samples with non significant statistical correlation $(\mathrm{p}>0.05)$. We found no significant correlation with other clinical parameter like Gleason score $(\mathrm{p}=0.72)$, histological grading $(\mathrm{p}=0.82)$ and tumor stages I-IV $(\mathrm{p}=0.31)$. This study does not support the evidence of XMRV infection in prostate cancer initiation and development in Indian population. Clearly, decision of this discrepancy will require more information and investigation with larger sample size.
\end{abstract}

\section{Introduction}

Prostate cancer $(\mathrm{PCa})$ is the second most prevalent, noncutaneous malignancies diagnosed among men in developing countries (Simard et al., 2002). But in India, recent epidemiological data showed that $\mathrm{PCa}$ became the top most cancer in men and is a major public health problem in India
(Fitzmaurice et al., 2015; Yeole, 2008). In most of human cancers, viruses are one of the etiological agents like human herpesvirus 8 causing Kaposi's sarcoma, hepatitis B and C virus causing hepetocellular carcinoma and human papillomavirus (HPV) causing cervical carcinoma (Hohn et al., 2009). 
Genetic and epidemiological evidences have suggested that prostate tissue is also prone to get infected with several viruses such as HPVs and polyomaviruses (SV 40) (Zambrano et al., 2002). It was shown from our laboratory that $41 \%$ prostate tumour biopsies were infected with HPVs in Indian population (Singh et al., 2015). Presently, there are several reports showing one of the known gamma-retroviruses, XMRV is imminent as a cancer causing infectious virus in prostate cancer.

XMRV has type $\mathrm{C}$ gammaretrovirus morphology with polygonal core and about $100 \mathrm{~nm}$ of diameter (Schlaberg et al., 2009). Viral genome is transcribed into a single unspliced transcript that is translated into polypeptides for the viral core (GAG), protease $(\mathrm{PRO})$, reverse transcriptase $(\mathrm{RT})$, and integrase (IN) proteins. Remarkably, previous studies showed that there is no other gamma-retroviruses infection in humans except XMRV. However, XMRV related xenotropic-MLV (X-MLV) is known to infect other species including cats, mice, and nonhuman primates causing leukemias, lymphomas, neurological diseases and immunodeficiencies in these species suggesting a plausible role for XMRV in PCa (Rezaei et al., 2013; Schlaberg et al., 2009). The detection of XMRV in human bio specimens is controversial being associated with two major human diseases, PCa (Qiu et al., 2010; Urisman et al., 2006) and chronic fatigue syndrome (Lombardi et al., 2009; Mikovits et al., 2010).

Several previous studies had revealed the infection of XMRV in PCa. The first report on XMRV infection in 2006 includes 86 patients with $\mathrm{PCa}$ in which $10 \%(9 / 86)$ patients were found positive (Urisman et al., 2006). The maximum prevalence of XMRV reported was $27 \%$ in $\mathrm{PCa}$ patients by using high sensitive PCR methods, FISH and IHC technique (Arnold et al., 2010; Schlaberg et al., 2009).

A very brief review of the published data in favour of presence of XMRV in clinical PCa illustrates the lack of consensus, however, some studies reflects its negative role in PCa. But in a separate study, it was shown that, XMRV gag DNA sequence was not found in 338 patients of PCa (Sfanos et al., 2008). Similar findings were also observed in other Caucasian population (Hohn et al., 2009).

As the fact, XMRV infection in human specimen and its role in $\mathrm{PCa}$, is still controversial and to the best of our knowledge no such study has been reported from India to evaluate its status in Indian population. Therefore, the present study has been designed to find out whether there is XMRV infection in Indian PCa patient present or not.

The main aim of this study has been designed XMRV infection in Indian PCa patient and co-relation with clinical pathological and demographic parameters of prostate cancer cases and BPH controls.

\section{Materials and Methods}

\section{Clinical Samples and tissue specimens}

A total of 235 surgically resected tissue specimens comprising of 105 prostate tumor tissues and 130 Benign prostate hyperplasia (BPH) tissues served as disease control of $\mathrm{PCa}$, were collected. None of these patients received any pre-operative radiation or chemotherapy. Only those cases which were fulfilling our inclusion criteria with a primary diagnosis of prostate cancer undergoing upfront surgery were taken up for the purpose of this study. All samples were collected from the Urology Department of Rajiv Gandhi Cancer Hospital, Rohini, Delhi (India) and RG Stone Urology and laparoscopy Hospital, 
Greater Kailash, New Delhi (India). Tissue samples were divided into two parts; one part was sent for histopathological diagnosis and other half was stored at $-70^{\circ} \mathrm{C}$ for molecular investigations. Histopathological grades and clinical staging were evaluated according to standard criteria by two pathologists independently. Only histopathologically confirmed cases were included for molecular analysis. Venous blood samples were collected for prostate specific antigen (PSA) determination. The study was approved by the ethical committees of the participating institutions and hospitals. Written informed consent was obtained from all the subjects included in the study.

\section{Genomic DNA isolation and qualitative/quantitative analysis}

High molecular-weight genomic DNA was extracted from 105 prostate tumor and 130 BPH tissue specimens by the standard protocol with proteinase $\mathrm{K}$ digestion followed by phenol-chloroform extraction procedure (Sambrook et al., 1989) which is routine method in our laboratory. The genomic DNA was quantified by gel electrophoresis on $1 \%$ agarose gel prepared in 1x Tris acetate EDTA buffer followed by staining with Ethidium Bromide (10mg/ml). Good quality/quantity high molecular weight DNA of 50-300 ng/ $\mu \mathrm{l}$ was obtained and band intensity was compared with the standard $1 \mu \mathrm{l}$ Hind IIIDNA molecular weight marker and stored for future use at $-20^{\circ} \mathrm{C}$.

\section{Nested PCR detection of XMRV}

High molecular weight genomic DNA were used for the detection of XMRV infection by using Nested PCR method according to protocol mentioned elsewhere (Arnold et al., 2010). For authentication of PCR results, we have used XMRV VP62 plasmid DNA as a positive control which was purchased from
Addgene plasmid repository, Cambridge, MA 02139 USA. Template DNA sample (50-100 ng per reaction) was used for the Polymerase Chain Reaction. First-round PCR was performed for outer fragment amplification using DNA template, 1X buffer, $2.5 \mathrm{mM}$ $\mathrm{MgCl}_{2}, 0.25 \mu \mathrm{M}$ each of dNTP, $200 \mathrm{nM}$ 6200R:CCCATGATGATGATGGCTTCCAG TATGC, 200nM 5922F: GCTAATGCTA CCT CCCTCCTGG, $2.5 \mathrm{U}$ of Taq under the following conditions: $94^{\circ} \mathrm{C}$ for 5 minutes followed by 40 cycles of $94^{\circ} \mathrm{C}$ for 30 seconds, $54.4^{\circ} \mathrm{C}$ for 30 seconds, $72^{\circ} \mathrm{C}$ for 45 seconds, and ending with $72^{\circ} \mathrm{C}$ for 2 minutes. The second round of PCR for inner fragment amplification consisted of $5 \mu \mathrm{L}$ of the first round PCR product, 1X buffer, $2.5 \mathrm{mM}$ $\mathrm{MgCl}_{2}, 0.25 \mu \mathrm{M}$ each of dNTP, $200 \mathrm{nM}$ 5942F: GGGGACGATGACAGACACTTT CC, 200nM 6159R: CACATCCCCAT TTGCCACAGT AG, 2.5U of Taq under the following conditions: $94^{\circ} \mathrm{C}$ for 5 minutes followed by 40 cycles of $94^{\circ} \mathrm{C}$ for 30 seconds, $51^{\circ} \mathrm{C}$ for 30 seconds, $72^{\circ} \mathrm{C}$ for 45 seconds, and ending with $72^{\circ} \mathrm{C}$ for 2 minutes. The PCR products were separated on a $2 \%$ agarose gel. The expected product for first- and secondround PCR was $278 \mathrm{bp}$ and $217 \mathrm{bp}$, respectively as compared with phiX174 DNA/BsuRI (HaeIII) Marker.

\section{Sequencing}

XMRV infected positive PCR amplified products were further used for direct sequencing for validation of results. Amplified PCR product obtained from nested PCR were purified by Exonuclease-Shrimp Alkaline Phosphatase (Exo-SAP) treatment method. Exo-SAP treated PCR products were directly sequenced according to the manufacturer's protocol with an automated DNA sequencer using ABI PrismTM3130 ${ }^{\mathrm{xl}}$ (Applied Biosystem, U.S.A) by using Big Dye Terminator v3.1 Cycle sequencing kit. The sequencing reaction was carried out using 
both forward and reverse primers. Sequences were compared with the reported reference prototype sequences of XMRV virus.

\section{Statistical Analysis}

All statistical analysis on the data was performed by the standard methods using Graphpad (Instat version 3.3) computer software and Fischer's Exact Test/ Chi Square Tests were performed as applicable. The findings were considered statistically significant at $\mathrm{p}$ values of 0.05 .

\section{Results and Discussion}

The Clinical and demographic characteristics of the $\mathrm{PCa}$ and $\mathrm{BPH}$ groups are listed in Table-1. A total of $105 \mathrm{PCa}$ cases and 130 $\mathrm{BPH}$ cases were recruited for the present study. The age distribution was almost similar for both PCa patients as well as BPH patients as $\quad 64.47 \pm 4.7 \quad \& \quad 67.18 \pm 8.37$ years, respectively. The serum PSA level $(>4 \mathrm{ng} / \mathrm{ml})$ was higher $94 \%(99 / 105)$ in PCa patients as compared to $51 \%(66 / 130)$ in $\mathrm{BPH}$ patient. In Histological grade, 24\% samples were having poorly differentiated adenocarcinoma (PDAC), 41\% samples were with moderately differentiated adenocarcinoma (MDAC) and $35 \%$ samples were having well differentiated adenocarcinoma (WDAC), whereas 36, 43, 16, 6 and 4 patients were having Gleason's score as 6, 7, 8, 9 and 10 respectively. Interestingly, almost twice numbers of cancer patient were found with stage III and IV as compared to stage I and II during the study.

\section{XMRV detection in PCa and BPH tissues}

A highly-sensitive, nested PCR assay for XMRV env was used to screen patients for XMRV infection. Each patient's specimen was screened in duplicate by using 50-100 ng of prostate tissue DNA. In this subset of patients, XMRV was detected in 5.4\% (7/130)
BPH tissue samples and in 7.6\% (8/105) PCa tissue samples (Table-1) (Fig 1). For validation and confirmation of the PCR results, amplified 217-bp PCR products were sequenced and compared with XMRV VP62 plasmid sequence which serves as positive control. The chromatograms obtained from the sequencing reaction were aligned for the similarity search with the consensus sequence of XMRV VP62 plasmid (Fig. 2). The nestedPCR product of 217-bp sequences from all positive patients showed 99-100\% nucleotide identity to each other. The high degree of sequence similarity with the sequence of VP62 suggests that the samples were attributable to the presence of XMRV DNA.

\section{Co-relations between XMRV status and clinico-pathological parameters and demographic characteristics}

The correlation of XMRV infection with various clinico-pathological and demographic characteristics was analysed (Table-2). Patients with higher PSA level were found prone to XMRV infection in both PCa as well as BPH samples. Interestingly, no statistically significant correlation was obtained between XMRV infection and PSA level ( $\mathrm{p}>0.05)$. Out of 8 XMRV positive PCa samples, 6 samples were having $\geq 7$ Gleason score $(p=0.72)$ with advance histological grading MDAC (4/8) and PDAC $(2 / 8) \quad(p=0.82)$. XMRV infected cases (7/8) were belonging to stage III and stage IV which showed non-significant correlation $(\mathrm{p}=0.31)$.

The existing capability of XMRV in human specimen and their power to initiation and progression of $\mathrm{PCa}$ is not well established till date. The previous studies have reported the presence of various viruses in prostate cancer development worldwide including XMRV (Fioriti et al., 2007; Zambrano et al., 2002). We need to understand its integration site in host genome, transmission routes, and its 
interaction with host immune system. Previously, various molecular approaches were focused on the detection of XMRV infection and integration site in the prostate carcinogenesis (Arnold et al., 2010; Kim et $a l ., 2010)$ but still it is not clear yet.

The present study was designed in the continuation of the question on XMRV infection in $\mathrm{PCa}$ in Indian population. To best of our knowledge it is the first report on XMRV in Indian patients with prostate adenocarcinoma. Our findings demonstrated there is no significant number of PCa cases have showed XMRV infection, 7.6\% (8/105) of the total PCa cases and 5.4\% (7/130) in BPH samples. This is in concordance with previous study from Pakistan where it was shown the presence of XMRV in almost 8\% in $50 \mathrm{PCa}$ biopsies but in contrast no $\mathrm{BPH}$ samples were shown to be positive with XMRV infection in their population (Baig et al., 2014). However, there are several other reports shown to have high prevalence of XMRV in prostate cancer patients in different populations (Arnold et al., 2010; Schlaberg et al., 2009; Urisman et al., 2006). In contrast, few studies from different geographical regions have also reported almost no XMRV infection in PCa (Gomes et al., 2014; Sakuma et al., 2011). These discrepancies in the status of XMRV infection worldwide may be due to different geographical area, ethnicity and different lifestyle habits may affect the prevalence of XMRV infection in prostate cancer.

Table.1 Demographical, clinico-pathological and XMRV status of studied prostate cancer and $\mathrm{BPH}$ controls from Indian population

\begin{tabular}{|c|c|c|}
\hline Characteristics & $\begin{array}{l}\text { BPH cases } \\
n=130(\%)\end{array}$ & $\begin{array}{c}\text { PCa cases } \\
\mathrm{n}=105(\%)\end{array}$ \\
\hline Age $($ mean \pm SD $)$ & $67.18 \pm 8.37$ & $64.47 \pm 4.7$ \\
\hline \multicolumn{3}{|l|}{ PSA(ng/ml) } \\
\hline $0-4.0$ & $64(49)$ & $6(6)$ \\
\hline $4.1-10.0$ & $37(28)$ & $21(20)$ \\
\hline $10.0-20.0$ & $20(15)$ & $27(26)$ \\
\hline$>20.0$ & $9(7)$ & $50(48)$ \\
\hline \multicolumn{3}{|l|}{ Gleason's Score } \\
\hline 6 & $0(0)$ & $36(34)$ \\
\hline 7 & $0(0)$ & $43(41)$ \\
\hline 8 & $0(0)$ & $16(15)$ \\
\hline 9 & $0(0)$ & $6(6)$ \\
\hline 10 & $0(0)$ & $4(4)$ \\
\hline \multicolumn{3}{|l|}{ Histological Grading } \\
\hline WDAC & $0(0)$ & $37(35)$ \\
\hline MDAC & $0(0)$ & $43(41)$ \\
\hline PDAC & $0(0)$ & $25(24)$ \\
\hline \multicolumn{3}{|l|}{ Tumor Stage } \\
\hline I+II & $0(0)$ & $38(36)$ \\
\hline III+IV & $0(0)$ & $67(64)$ \\
\hline \multicolumn{3}{|l|}{ XMRV Status } \\
\hline Positive & $7(5.4)$ & $8(7.6)$ \\
\hline Negative & 123(94.6) & $97(92.4)$ \\
\hline
\end{tabular}


Table.2 Correlation between XMRV status and clinico-pathological parameters of prostate cancer cases and BPH controls.

\begin{tabular}{|c|c|c|c|c|}
\hline & \multicolumn{2}{|c|}{ BPH } & \multicolumn{2}{|c|}{ PCa } \\
\hline & $\begin{array}{c}\text { Negative } \\
\text { 123(\%) }\end{array}$ & $\begin{array}{c}\text { Positive } \\
7(\%) \\
\end{array}$ & $\begin{array}{c}\text { Negative } \\
97(\%)\end{array}$ & $\begin{array}{c}\text { Positive } \\
8(\%)\end{array}$ \\
\hline \multicolumn{5}{|l|}{$\begin{array}{l}\text { PSA } \\
\end{array}$} \\
\hline $0-4.0$ & $63(51)$ & $1(14)$ & $6(6)$ & $1(12.5)$ \\
\hline $4.1-10.0$ & $35(28)$ & $2(29)$ & $20(21)$ & $1(12.5)$ \\
\hline $10.0-20.0$ & $17(14)$ & $3(43)$ & $24(25)$ & $1(12.5)$ \\
\hline$>20.0$ & $8(7)$ & $1(14)$ & $47(48)$ & $5(62.5)$ \\
\hline P Value & \multicolumn{2}{|c|}{0.15} & \multicolumn{2}{|c|}{0.74} \\
\hline \multicolumn{5}{|c|}{ Gleason's Score } \\
\hline 6 & - & - & $34(35)$ & $2(25)$ \\
\hline 7 & - & - & $40(41)$ & $3(37.5)$ \\
\hline 8 & - & - & $14(15)$ & $2(25)$ \\
\hline 9 & - & - & $5(5)$ & $1(12.5)$ \\
\hline 10 & - & - & $4(4)$ & 0 \\
\hline P Value & & & \multicolumn{2}{|c|}{0.72} \\
\hline \multicolumn{5}{|c|}{ Histological Grading } \\
\hline WDCC & - & - & $35(36)$ & $2(25)$ \\
\hline MDCC & - & - & $39(40)$ & $4(50)$ \\
\hline PDCC & - & - & $23(24)$ & $2(25)$ \\
\hline P Value & & & \multicolumn{2}{|c|}{0.82} \\
\hline \multicolumn{5}{|c|}{ Tumor Stage } \\
\hline I+II & - & - & $37(38)$ & $1(12.5)$ \\
\hline III+IV & - & - & $60(62)$ & $7(87.5)$ \\
\hline P Value & & & \multicolumn{2}{|c|}{0.31} \\
\hline
\end{tabular}


Fig.1a Gel representative for detection of XMRV Infection in first round of Nested-PCR product

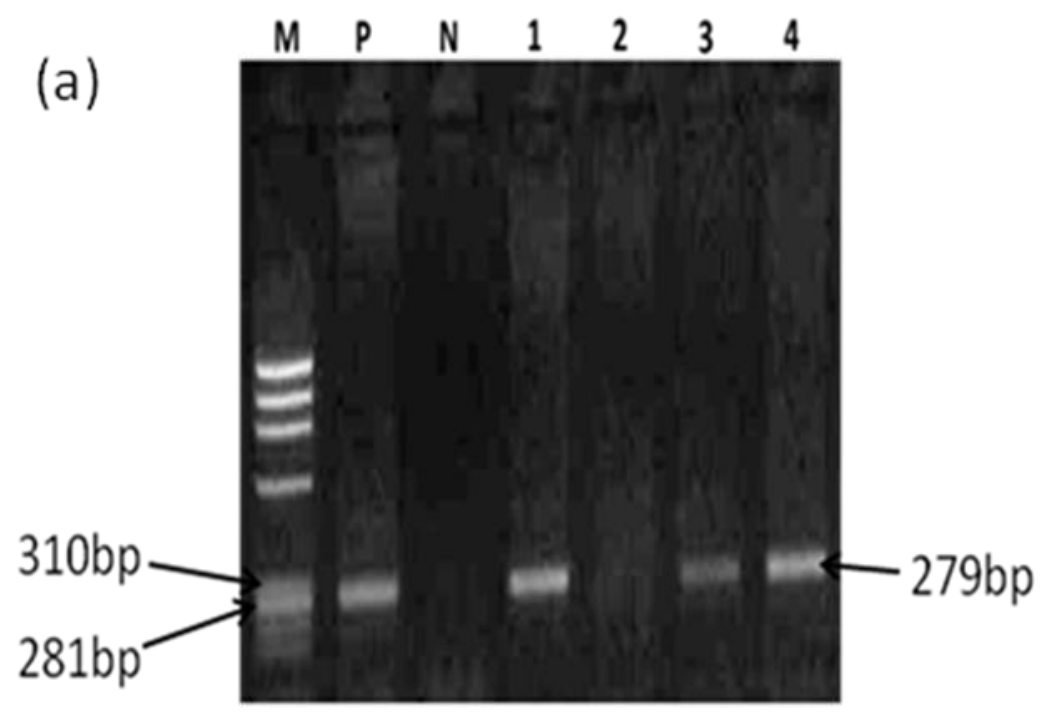

Fig.1b Gel representative for detection of XMRV Infection in second round of Nested-PCR product

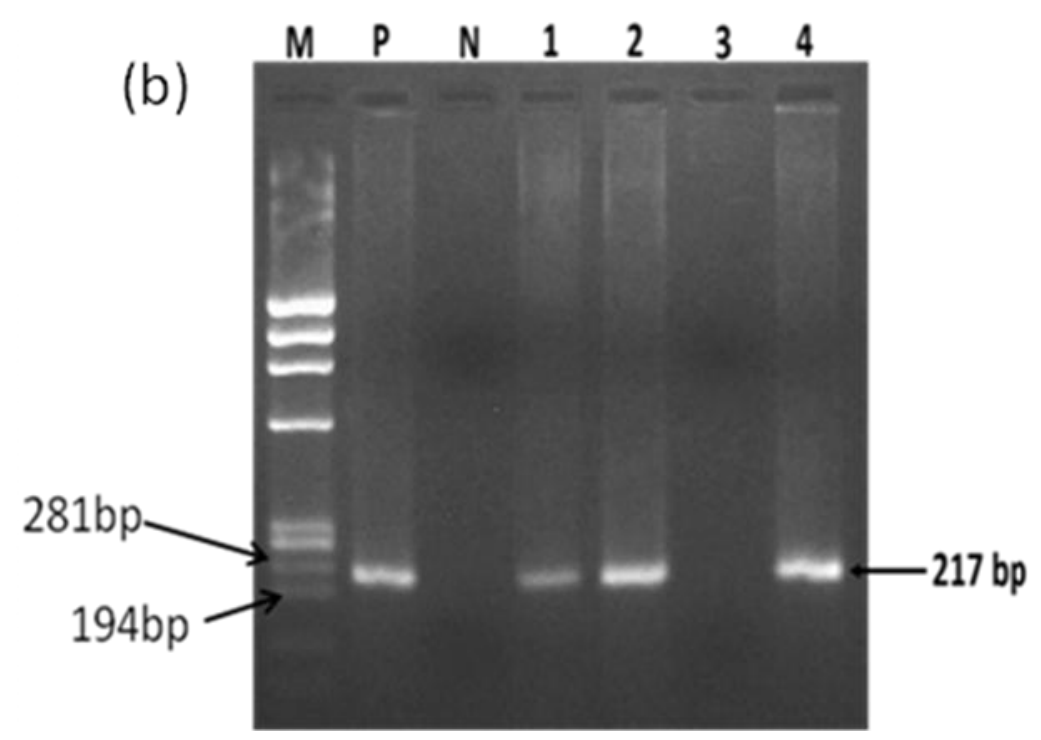

$2 \%$ agarose gel represents the amplification of nested-PCR

Lane M: фx 174 DNA digested marker,

Lane P: positive control (plasmid DNA) sample;

Lane N: Negative control.

Lane 1-2: BPH patient sample

Lane 3-4: Prostate cancer patient sample 
Fig.2 Chromatogram showing similar alignment between control XMRV VP 62 plasmid DNA sample (reference sequence) and prostate cancer patient sample

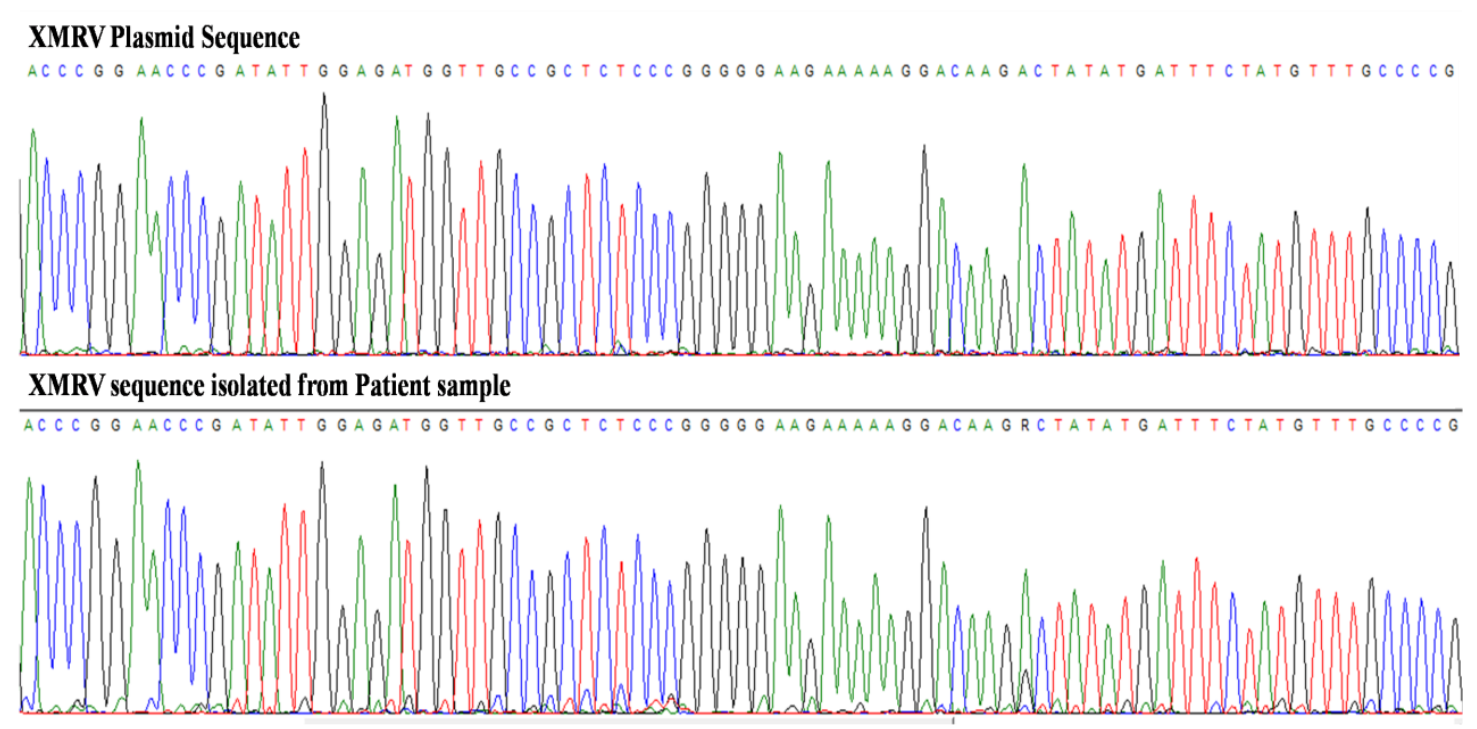

From the present study, it was found that nested PCR assay for XMRV env to be capable of detecting XMRV infection in PCa. PCR amplicon sequence of XMRV positive prostate samples was all most similar to XMRV V62 plasmid sequence which was used as positive control. This nested PCR interpretation would be consistent with few other reports (Arnold et al., 2010; Danielson et al., 2010). We did not find any association between XMRV infection and various clinical pathological parameters of $\mathrm{PCa}$, including PSA level, Gleason score, histological grade and tumor stage. Few studies are in good agreement with our finding on Gleason score (Baig et al., 2014; Sakuma et al., 2011) but in contrast, other study showed the correlation between XMRV infection with patient having higher Gleason score (Schlaberg et al., 2009). As the prevalence of XMRV infection in the studied population is very low, additional study with higher sample size will be required to evaluate a correlation between XMRV infection and Gleason score.

In conclusion, the present study strengthens the hypothesis that the prostate gland in males represents a complex niche where multiple infections with oncogenic potential like viruses may be one of the etiological agent and implicates the potential role in progression of prostate cancer. But this study does not support the evidence of XMRV infection in prostate cancer initiation and development. To our knowledge, this is the first pioneer study evaluating the frequency of XMRV infection in prostate cancer in India. Clearly, decision of these discrepancy will required more information and investigation with larger sample size.

\section{Acknowledgements}

The authors thank patients, their relatives and clinicians for their support and cooperation. The study was supported by funds provided by ICPO-ICMR, Noida to MB.

\section{Conflict of Interest}

The authors have declared no conflicts of interest. The authors alone are responsible for the content and writing of the research article. 


\section{References}

Arnold, R.S., Makarova, N.V., Osunkoya, A.O., Suppiah, S., Scott, T.A., Johnson, N.A., Bhosle, S.M., Liotta, D., Hunter, E., Marshall, F.F., Ly, H., Molinaro, R.J., Blackwell, J.L., Petros, J.A., 2010. XMRV infection in patients with prostate cancer: novel serologic assay and correlation with PCR and FISH. Urol., 75, 755-61.

Baig, F.A., Mirza, T., Khanani, R., Khan, S., 2014. Detection of Xenotropic murine leukemia virus-related virus in prostate biopsy samples. J. Coll. Physicians Surg. Pak., 24, 636-9.

Danielson, B.P., Ayala, G.E., Kimata, J.T., 2010. Detection of xenotropic murine leukemia virus-related virus in normal and tumor tissue of patients from the southern United States with prostate cancer is dependent on specific polymerase chain reaction conditions. $J$. Infect. Dis., 202, 1470-7.

Fioriti, D., Russo, G., Mischitelli, M., Anzivino, E., Bellizzi, A., Di Monaco, F., Di Silverio, F., Giordano, A., Chiarini, F., Pietropaolo, V., 2007. A case of human polyomavirus $\mathrm{Bk}$ infection in a patient affected by late stage prostate cancer: could viral infection be correlated with cancer progression? Int. J. Immunopathol. Pharmacol., 20, 405-11.

Fitzmaurice, C., Dicker, D., Pain, A., Hamavid, H., Moradi-Lakeh, M., MacIntyre, M.F., Allen, C., Hansen, G., Woodbrook, R., Wolfe, C., Hamadeh, R.R., Moore, A., Werdecker, A., Gessner, B.D., Te Ao, B., McMahon, B., Karimkhani, C., Yu, C., Cooke, G.S., Schwebel, D.C., Carpenter, D.O., Pereira, D.M., Nash, D., Kazi, D.S., De Leo, D., Plass, D., Ukwaja, K.N., Thurston, G.D., Yun Jin, K., Simard, E.P., Mills, E., Park, E.K., Catala-
Lopez, F., deVeber, G., Gotay, C., Khan, G., Hosgood, H.D., 3rd, Santos, I.S., Leasher, J.L., Singh, J., Leigh, J., Jonas, J., Sanabria, J., Beardsley, J., Jacobsen, K.H., Takahashi, K., Franklin, R.C., Ronfani, L., Montico, M., Naldi, L., Tonelli, M., Geleijnse, J., Petzold, M., Shrime, M.G., Younis, M., Yonemoto, N., Breitborde, N., Yip, P., Pourmalek, F., Lotufo, P.A., Esteghamati, A., Hankey, G.J., Ali, R., Lunevicius, R., Malekzadeh, R., Dellavalle, R., Weintraub, R., Lucas, R., Hay, R., Rojas-Rueda, D., Westerman, R., Sepanlou, S.G., Nolte, S., Patten, S., Weichenthal, S., Abera, S.F., Fereshtehnejad, S.M., Shiue, I., Driscoll, T., Vasankari, T., Alsharif, U., Rahimi-Movaghar, V., Vlassov, V.V., Marcenes, W.S., Mekonnen, W., Melaku, Y.A., Yano, Y., Artaman, A., Campos, I., MacLachlan, J., Mueller, U., Kim, D., Trillini, M., Eshrati, B., Williams, H.C., Shibuya, K., Dandona, R., Murthy, K., Cowie, B., Amare, A.T., Antonio, C.A., Castaneda-Orjuela, C., van Gool, C.H., Violante, F., Oh, I.H., Deribe, K., Soreide, K., Knibbs, L., Kereselidze, M., Green, M., Cardenas, R., Roy, N., Tillman, T., Li, Y., Krueger, H., Monasta, L., Dey, S., Sheikhbahaei, S., Hafezi-Nejad, N., Kumar, G.A., Sreeramareddy, C.T., Dandona, L., Wang, H., Vollset, S.E., Mokdad, A., Salomon, J.A., Lozano, R., Vos, T., Forouzanfar, M., Lopez, A., Murray, C., Naghavi, M., 2015. The Global Burden of Cancer 2013. JAMA Oncol., 1, 505-27.

Gomes, S.T., Imbiriba, L., Burbano, R.R., Silva, A.L., Feitosa, R.N., CayresVallinoto, I.M., Ishak Mde, O., Ishak, R., Vallinoto, A.C., 2014. Lack of evidence for human infection with Xenotropic murine leukemia virusrelated virus in the Brazilian Amazon 
basin. Rev. Soc. Bras. Med. Trop., 47, 302-6.

Hohn, O., Krause, H., Barbarotto, P., Niederstadt, L., Beimforde, N., Denner, J., Miller, K., Kurth, R., Bannert, N., 2009. Lack of evidence for xenotropic murine leukemia virus-related virus(XMRV) in German prostate cancer patients. Retrovirol., 6, 92.

Kim, S., Rusmevichientong, A., Dong, B., Remenyi, R., Silverman, R.H., Chow, S.A., 2010. Fidelity of target site duplication and sequence preference during integration of xenotropic murine leukemia virus-related virus. PLoS One, 5, e10255.

Lombardi, V.C., Ruscetti, F.W., Das Gupta, J., Pfost, M.A., Hagen, K.S., Peterson, D.L., Ruscetti, S.K., Bagni, R.K., Petrow-Sadowski, C., Gold, B., Dean, M., Silverman, R.H., Mikovits, J.A., 2009. Detection of an infectious retrovirus, XMRV, in blood cells of patients with chronic fatigue syndrome. Sci., 326, 585-9.

Mikovits, J.A., Lombardi, V.C., Pfost, M.A., Hagen, K.S., Ruscetti, F.W., 2010. Detection of an infectious retrovirus, XMRV, in blood cells of patients with chronic fatigue syndrome. Virulence, 1 , 386-90.

Qiu, X., Swanson, P., Luk, K.C., Tu, B., Villinger, F., Das Gupta, J., Silverman, R.H., Klein, E.A., Devare, S., Schochetman, G., Hackett, J., Jr., 2010. Characterization of antibodies elicited by XMRV infection and development of immunoassays useful for epidemiologic studies. Retrovirol., 7, 68.

Rezaei, S.D., Hearps, A.C., Mills, J., Pedersen, J., Tachedjian, G., 2013. No association between XMRV or related gammaretroviruses in Australian prostate cancer patients. Virol. J., 10, 20.
Sakuma, T., Hue, S., Squillace, K.A., Tonne, J.M., Blackburn, P.R., Ohmine, S., Thatava, T., Towers, G.J., Ikeda, Y., 2011. No evidence of XMRV in prostate cancer cohorts in the Midwestern United States. Retrovirol., $8,23$.

Sambrook J, Fritsh EF, T, M., 1989. Molecular Cloning: A laboratory Manual, Vol. 1.

Schlaberg, R., Choe, D.J., Brown, K.R., Thaker, H.M., Singh, I.R., 2009. $\mathrm{XMRV}$ is present in malignant prostatic epithelium and is associated with prostate cancer, especially high-grade tumors. Proc. Natl. Acad. Sci. U S A. 106, 16351-6.

Sfanos, K.S., Sauvageot, J., Fedor, H.L., Dick, J.D., De Marzo, A.M., Isaacs, W.B., 2008. A molecular analysis of prokaryotic and viral DNA sequences in prostate tissue from patients with prostate cancer indicates the presence of multiple and diverse microorganisms. Prostate, 68, 306-20.

Simard, J., Dumont, M., Soucy, P., Labrie, F., 2002. Perspective: prostate cancer susceptibility genes. Endocrinol., 143, 2029-40.

Singh, N., Hussain, S., Kakkar, N., Singh, S.K., Sobti, R.C., Bharadwaj, M., 2015. Implication of high risk human papillomavirus HR-HPV infection in prostate cancer in Indian population--a pioneering case-control analysis. Sci Rep., 5, 7822.

Urisman, A., Molinaro, R.J., Fischer, N., Plummer, S.J., Casey, G., Klein, E.A., Malathi, K., Magi-Galluzzi, C., Tubbs, R.R., Ganem, D., Silverman, R.H., DeRisi, J.L., 2006. Identification of a novel Gammaretrovirus in prostate tumors of patients homozygous for R462Q RNASEL variant. PLoS Pathog., 2, e25.

Yeole, B.B., 2008. Trends in the prostate 
cancer incidence in India. Asian Pac. $J$. Cancer Prev., 9, 141-4.

Zambrano, A., Kalantari, M., Simoneau, A., Jensen, J.L., Villarreal, L.P., 2002. Detection of human polyomaviruses and papillomaviruses in prostatic tissue reveals the prostate as a habitat for multiple viral infections. Prostate, 53, 263-76.

\section{How to cite this article:}

Kapil Bandil, Anoop Kumar, Atika Dogra, Sudhir K. Rawal, D.C. Doval, Anil K. Varshney, Mausumi Bharadwaj. 2017. Is a Retrovirus (XMRV) Risk Factor for Prostate Cancer in Indian Population. Int.J.Curr.Microbiol.App.Sci. 6(1): 609-619. doi: http://dx.doi.org/10.20546/ijcmas.2017.601.074 